\title{
Maximal inter-incisal distance in healthy school children in Switzerland
}

\author{
H van Waes ${ }^{1}$, C Langerweger ${ }^{1}$, L Mueller ${ }^{1}$, CJ Kellenberger ${ }^{2}$, RK Saurenmann ${ }^{3^{*}}$ \\ From 18th Pediatric Rheumatology European Society (PReS) Congress \\ Bruges, Belgium. 14-18 September 2011
}

\section{Background}

The temporo-mandibular joint (TMJ) is affected in about $50 \%$ of children with juvenile idiopathic arthritis (JIA). Diagnosis and treatment are often delayed because of lack of symptoms in early TMJ arthritis. A reduced mouth opening capacity may be one of the first clinical signs of TMJ involvement.

\section{Aim}

To create age related percentiles for the maximal mouth opening capacity of healthy children.

\section{Methods}

All recordings of the maximal inter-incisal distance as measured at the yearly routine school dental examinations of school children in the city of Zurich, Switzerland, between August 2009 and August 2010 were extracted from the database. LMS ChartMakerPro version 2.3 (Medical Research Council, UK) was used to calculate age and sex related reference centiles.

\section{Results}

A total of 20'709 measurements (10'058 girls, 10'651 boys) were available for the analysis. The median age (range) was 9.92 years $(3.25-18.33)$ for girls and 10.00 years (2.8318.67) for boys. The mean inter-incisal distance (range) was $45 \mathrm{~mm}$ (25-69) for girls and $45 \mathrm{~mm}$ (25-70) for boys. Age related percentiles were created for girls and boys separately, showing the $3^{\text {rd }}, 10^{\text {th }}, 25^{\text {th }}, 50^{\text {th }}, 75^{\text {th }}, 90^{\text {th }}$, and $97^{\text {th }}$ percentile from 3 through 18 years of age.

\footnotetext{
* Correspondence: traudel.saurenmann@kispi.uzh.ch

${ }^{3}$ Department for Pediatric Rheumatology, Children's Hospital; University of Zurich, Switzerland
}

Full list of author information is available at the end of the article

\section{Conclusion}

In these 20'709 unselected school children the interincisal distance increased with age but showed a wide range within children of the same age. These percentiles may be a helpful tool in assessing the range of TMJ movement in children with JIA.

\section{Author details}

${ }^{1}$ Department for Orthodontics and Pediatric Dentistry, University of Zurich, Switzerland. Department for Diagnostic Imaging, Children's Hospital, University of Zurich, Switzerland. ${ }^{3}$ Department for Pediatric Rheumatology, Children's Hospital; University of Zurich, Switzerland.

Published: 14 September 2011

doi:10.1186/1546-0096-9-S1-P147

Cite this article as: van Waes et al:: Maximal inter-incisal distance in healthy school children in Switzerland. Pediatric Rheumatology 20119 (Suppl 1):P147.

\section{Submit your next manuscript to BioMed Central and take full advantage of: \\ - Convenient online submission \\ - Thorough peer review \\ - No space constraints or color figure charges \\ - Immediate publication on acceptance \\ - Inclusion in PubMed, CAS, Scopus and Google Scholar \\ - Research which is freely available for redistribution

C Biomed Central

() 2011 van Waes et al; licensee BioMed Central Ltd. This is an open access article distributed under the terms of the Creative Commons Attribution License (http://creativecommons.org/licenses/by/2.0), which permits unrestricted use, distribution, and reproduction in any medium, provided the original work is properly cited. 